\title{
EUROPEAN STATES IN A BOUT OF CORPORATE TAX COMPETITION
}

\section{- Anna Banociova, Slavomira Tablova}

\begin{abstract}
In the corporate environment, globalization supports possibilities of mobile bases transfers among states and therefore changes in the taxable income. Differences in tax systems as well as in the level of corporate income tax revenues deserve attention in the context of tax competition. Experts on tax competition in the field of corporate taxation can be divided into those who perceive it positively, particularly because of its influences on the economic growth of the state, and those who consider it as harmful, especially because of the possibility of tax base transfers among states along with the impossibility of ensuring effective allocation of tax resources. The main objective of this paper is to characterize tax competition between EU member states over a ten-year period and to assess whether states are competitive in the field of corporate taxation. Tax competitiveness among states is perceived based on the level of corporate income tax revenues in relation to GDP. Based on the examination of determinants of corporate income tax revenues, a draft of the econometric model of panel regression has been specified (fixed model with individual effects) and is compiled from the main tax and macroeconomic determinants that influence tax competitiveness in the field of corporate taxation. The conclusion confirms that there is tax competition in the field of corporate tax between EU states, and there is a statistically significant relation between the development of corporate income tax revenues and the determinants of tax competitiveness that are influenced in the context of corporate taxation.
\end{abstract}

Keywords: corporate income tax revenues, tax competitiveness, tax rates, foreign direct investments, European Union states

JEL Classification: $\mathrm{H} 25$

Received: November, 2018

1st Revision: April, 2019

Accepted: June, 2019

\section{INTRODUCTION}

In order to accept the corporate income tax of a legal person (LP) of the company in terms of its economic policy, an efficient tax system needs to be incorporated. The ideal tax system is fair, efficient, effective and simple. These criteria are also used as a base for tax creation, not exempting corporate income tax the LP status (OECD, 2014). In general, it is possible to agree that member states dispose of approximately the same structure of direct taxes in their tax systems and therefore maintain the same position regarding corporate income tax of LP. Nevertheless, 
there are many differences among states in terms of the taxation of LP, for example in the form of tax rates, establishing tax bases, and implementing other legislative regulations (Auerbach, 2006). Analogous to previous years, also in the year 2017 most states in the world reduced the level of tax rates for taxation of LP. The literature states that tax competition between states is one of the reasons for the decline in tax rates (Remeur, 2015).

Experts on tax competition can be divided into those who perceive it positively, particularly because of influencing the economic growth of the state and increasing the efficiency of public spending (Winner, 2005), and those who consider it as harmful, especially because of the possibility of tax base transfers between states and the impossibility of ensuring an effective allocation of tax resources (Griffith \& Klemm, 2004; Stiglitz \& Rosengard, 2015; Bazel et al., 2018). The differences among states in terms of the tax burden of corporate tax have caused a change in the concentration of tax revenues coming from mobile tax bases, to which the profits of companies belong. If the effect of variances in tax regimes favours one location of an enterprise over another and also a change in taxable income in the state, then in the context of tax competition, the differences between corporate income tax revenues (CITR) of states deserve attention.

The income tax of LP is not directly regulated by the European legislation. The process of harmonization in the field of direct taxation in the EU is not intensive, especially because of the unanimous agreement of all member states. EU activity focuses on the principles of the single market, harmonization of standards for LP taxation, and specification of objectives, e.g. in the form of prevention of tax evasion or removal of double taxation. Streif (2015) states that the general decline of the corporate tax rates in the EU member states is the result of existing tax competition between these states and is not the result of existing tax competition between EU states and other world powers. The openness of economies and economic integration among states represents the key principle of globalization (Kalaš et al., 2017). Tax harmonization will not stop at the EU level in a globalized world. Possible tax harmonization could reduce the pressures of tax competition within the EU member states, but external pressure would cause these countries to lose their tax advantage compared to other world powers in the context of a quick response to emerging changes (Schön, 2003). The present paper deals only with the extent to which the tax competition is present in the EU among the member states. Davies \& Voget (2008) have made conclusion that the EU enlargement has intensified an intra-region tax competition.

The main objective of the paper is to characterize the tax competition among the EU member states, assess whether the states are competitive in the field of corporate tax, and explore the factors that determine this competitiveness.

\section{BACKGROUND AND LITERATURE}

Despite the efforts to coordinate and harmonize the income tax regimes of LP in the EU member states, the efforts of individual member states to maintain tax sovereignty have been observed (Široký et al., 2006; European Commission, 2018). The balance between the tax cooperation and tax competition among the member states may exist and is necessary, especially specific features of tax systems distort tax competition. According to Winner (2005), the term tax competition is understood in the literature as "a situation where tax jurisdictions in a particular jurisdiction 
induce tax externalities in the other jurisdictions". According to Mitchell (2004), fiscal competition exists in cases in which individual economic entities can change the fiscal pressure from states with a higher tax burden into states with a lower tax burden.

Keen (2017) has examined the relation between the tax competition and tax policy. The author expressed the conclusion that a short-term tax incentives policy can contribute to an increase of the state's competitiveness. The Global Competitiveness Report defines competitiveness as "the set of institutions, policies and factors that determine the level of productivity of a country" (OECD, 2011). One approach to examining the impact of tax on competitiveness is to consider how fiscal policy and administration impact the 'pillars' and hence productivity. In practice, most taxes (not only the corporate income tax) can have an impact on competitiveness (OECD, 2011). Changes in the tax policy can contribute to changes in tax competitiveness (Matthews, 2011) by:

1. increasing the tax revenues in a way that is generally accepted as fair (more likely to achieve a high level of voluntary compliance)

2. good administration that is effective in eliminating tax evasion, strengthens social cohesion, and does not provide any unjustified advantage

3. effective tax administration that is not open to corruption

4. low transaction costs and tax burden on taxpayers

5. by creating a transparent tax policy

Devereux et al. (2008) evaluated 21 OECD states and compared them in relation to the level of their corporate taxes in terms of competitiveness by comparing statutory and implicit tax rates. The authors have found convincing evidence about the existence of tax competition in statutory tax rates (STR). Overesch \& Rincke (2011) draw similar conclusions considering the EU states. STR can be considered as a significant determinant if they are stable and without frequent changes (Clausing, 2007). Declining tax rates have led to increasing attempts to seek international coordination and preservation of CITR. In the case of maximum applicable tax rates, there is a tendency to leave this competition and market forces to be settled among the states themselves. The level of STR at the natural upper limit means that any increase in the rate will result in a decrease of aggregate tax revenues. Government discussions often lead to efforts to lower the tax rates for LP due to two reasons: the first is larger investment and job creation, with the second reason lower rates and base broadening of the counter to the multinational profit shifting through transfer pricing and financing decisions to help preserve revenues (Mintz \& Weichenrieder, 2010; Bazel et al., 2018).

Evaluating the tax competitiveness, Bazel et al. (2018) consider an effective tax rate on new investment - called the marginal effective tax rate (METR) as a summary indicator. The indicator takes into account various taxes that directly affect corporate profitability (Congressional Budget Office's, 2017; Bazel et al., 2018). In the case of the tax growth, after-tax profits are lower, an enterprise reduces investment costs and more often undertakes projects with a fairly high rate of return to cover higher financial costs and taxes. The indicator METR is most commonly used in fiscal policy analyses with the objective of understanding the tax structure and its impact on 
capital investment. Devereux et al. (2008) examined how OECD states are competing with each other in the field of corporate taxes. The authors examined the level of METR and chose the place of their profit in response to differences in STRs. States compete with each other for both tax competition parameters, STR for profit and METR for capital.

Present empirical studies most often focus on CITR determinants with an emphasis on the yet unobserved tax base and tax system of LP in individual states. The income tax of LP is characterized by the basic and complementary structural components of a tax law. Based on the national law and the adoption of fiscal interventions, the individual member states also influence the level of CITR by the tax base. This also depends on the non-rate aspects of the tax system. Relations between the tax-based changes in legislation and the tax-rate changes appear to be essential in assessing a state's tax competitiveness. Report of 'International Tax Competitiveness Index' compiled by Tax Foundation states that the tax-base structure should be for taxpayers simple with the aim to support economic development and also with a sufficient increase in tax revenues for the development of the state. The global trend in the context of changes in the corporate tax structure is a reduction of STRs and the adoption of measures that extend the tax base. The 'Tax Competitiveness Index' (compiled from 40 categories) determines how competitive and neutral the tax system is. The rate of tax attractiveness of the environment for LP is monitored through the 'Tax Attractiveness Index'. The composite indicator captures a range of tax aspects relevant to a decision-making in the area of company's location, reflecting not only the tax rate, but also other aspects, for example the anti-evasion rules, the straight line depreciation methods, the declining balance method or the accelerated depreciation method, the loss of Carry-forward or Carry-back options, the number of years of their transfer, alternatively their abolition, the application of tax concessions and incentives, for example for science and research, or the transfer pricing rules. The growth of the Tax Attractiveness Index assumes more appropriate legislative and tax conditions and tax environment for LP in the state, making it more attractive to domestic and foreign LP, thereby the corporate sector increases and consequently CITRs increase. Other attributes influencing a decision to place the mobile capital of a company, or more precisely the entire company, may be the principles of interest rate deduction, valuation methods, accruals management rules, special tax regimes for particular localization zones. Kawano \& Slemrod $(2012,2016)$ or Schanz et al. (2017) point out that due to the complexity of tax policy legislation, it is justified to state the difficulty of identifying the tax base determinants in order to maximize CITRs to government budgets.

Applying permanently lower tax rates or taking tax-based measures makes some states more competitive, and also are able to create tax competition and lead on to attracting and influencing foreign investment in tax field (Stolojan \& Tatarcan, 2002). The existence of tax competition is considered to be beneficial for reasons of rational fiscal policy making, facilitating economic growth or creating a more suitable corporate environment (OECD, 2011; Mitchell, 2004; Chirculescu, 2018). Ascendant globalization affects the behaviour of enterprises and the decision of placing their mobile capital and the size of their international capital flows. It is foreign direct investments (FDI) in relation to GDP that has grown massively over the last 20 years. Devereux et al. (2008) considered the transfer of mobile capital due to more favourable tax legislation and a reduction in the corporate sector as a reason for the change of the level of CITRs. Gropp \& Kos- 
tial (2000) noted a strong dependence among FDI growth, choice of tax regime in the host state, and CITRs (similar to Slemrod, 1990; Devereux \& Freeman, 1995; Bénassy-Quéré et al., 2000).

The state is competitive and attractive for FDI inflows if its tax rates are stable, without frequent changes. A decrease in tax rates has a positive effect on the state where FDI inflows and the growth of taxable income occurs. In another case, tax competition has a negative impact because there is an outflow in FDI as well as a decrease in the level of taxable income. A decrease in taxable income is influenced by the decline in CITRs and consequently a decline in economic growth in states with a higher tax burden (Edwards \& Rugy, 2002; Streif, 2015). In practice, the range of empirical estimates of the responsiveness of FDI in relation to corporate tax rates is quite wide and this makes clear cut conclusions more difficult. However, this elasticity appears to have increased over the time and the international competition for FDI thus reinforces the wider competitiveness arguments discussed in the previous section for a tax regime that fosters a good climate for investment and innovation (OECD, 2011).

States with a greater international integration dispose of higher CITRs at low STRs due to the higher sensitivity of the tax base (Clausing, 2007; Brill \& Hassett, 2007). Motta and Norman (1996) describe why regional tax competition may be more intensive than competition within states from different regional blocks. In case that trading costs in a single region are low enough, this is more likely to affect companies' decision to place FDI outside the home state. According to Motta and Norman (1996), tax competition among states intensifies when states are motivated to compete with each other attracting FDI (permanently lower export costs) and, in case of less divergent FDI costs among states, it makes them more competitive even in less integrated areas. Baltagi et al. (2007) show that free trade agreements did not affect trade alone but also the amount of FDI in Europe. An important stimulus affecting the allocation of investment in one state leads to a reduction of investments in other states, or more precisely regions.

In the world of level of CITRs, the determinant of state's tax competitiveness is the productivity of the corporate environment and its size. A suitable indicator of the corporate environment is the globalization index, which is a reflection of three economic, social, and political dimensions, and is also a manifestation of the growing interdependence of states but also multinational companies. This index may, under certain conditions, lead to a corporate sector growth and corporate income tax revenues growth. The level of CITRs is influenced by a group of cyclical variables, in the form of inflation and unemployment rates.

\section{METHODOLOGY, RESEARCH OBJECTIVE AND DATA}

Based on the main objective of the paper, tax competitiveness among states is perceived by the level of CITRs in relation to GDP. According to the main objectives of our research, we have formulated two following research hypotheses:

Hypothesis No. 1: "There is a tax competition in the field of corporate tax between the states of the European Union."

Hypothesis No. 2: "There is a statistically significant relation between the development of corporate income tax revenues and the determinants of tax competitiveness that affect it." 
To research the stated hypotheses, the econometric model is proposed, set with the emphasis on factors influencing the corporate tax environment within the context of tax competitiveness. The model is based on the decomposition of the share of CITRs in relation to GDP (similar to Clausing, 2007). The level of CITRs is influenced by tax variables, international factors that have a link to tax competitiveness among states and other factors affecting the corporate environment in the state. The model is expressed by the following relation:

$$
\begin{aligned}
\frac{C I T R}{H D P_{i, T}}=\beta_{0} & +\sum_{k=1}^{l} \beta_{k} \operatorname{Tax}_{k_{i, T}}+\sum_{m=l+1}^{n} \beta_{m} \text { International }_{m_{i, T}} \\
& +\sum_{r=m+1}^{s} \beta_{r} \text { Other }_{r_{i, T}}+\mu_{T}+\varepsilon_{i, T}
\end{aligned}
$$

where CITR/HDP ${ }_{i, T}$ are CITRs in relation to GDP, $\operatorname{Tax}_{i, T}$ represents a set of tax variables, International $_{i, T}$ represents a set of external macroeconomic variables, which dispose of the link to tax competitiveness among states, Other $r_{i, T}$ represents a set of other corporate variables that affect the corporate sector and its competitiveness, $\beta$ represents individual regression coefficients, $\mu_{, T}$ are annual effects, $\varepsilon_{, T}$ represents a random independent error, states are labelled with index $\mathrm{i}$, and the time is labelled with index $\mathrm{T}$.

The input explanatory variables in the three sets of variables and their impact on the explained variable, which is CITRs in relation to GDP, within the EU-28 and their expected impact are included in the table below (Tab. 1).

\begin{tabular}{|c|c|c|c|c|}
\hline Set & Variable & Labelled as & Effect & Relation \\
\hline \multirow{5}{*}{$\stackrel{\nexists}{\sim}$} & Statutory tax rate & STR & + & $\begin{array}{l}\text { A higher tax rate leads to } \\
\text { higher CITRs. }\end{array}$ \\
\hline & $\begin{array}{l}\text { Marginal effective tax } \\
\text { rate }\end{array}$ & METR & + & \\
\hline & $\begin{array}{l}\text { Statutory tax rate to the } \\
\text { power of } 2\end{array}$ & STR2 & - & $\begin{array}{l}\text { Confirmation of nonlin- } \\
\text { ear relation between tax } \\
\text { rate and CITRs. }\end{array}$ \\
\hline & $\begin{array}{l}\text { Marginal effective tax } \\
\text { rate to the power of } 2\end{array}$ & METR2 & - & \\
\hline & $\begin{array}{l}\text { Anti-evasion rules } \\
(\text { dummy }=1)\end{array}$ & Factor(Anti) & + & $\begin{array}{l}\text { The established rules } \\
\text { should affect the exten- } \\
\text { sion of tax base and } \\
\text { higher CITRs. }\end{array}$ \\
\hline
\end{tabular}

Tab. 1 - Determinants of CITRs and their expected impact. Source: own research 


\begin{tabular}{|c|c|c|c|c|}
\hline \multirow{5}{*}{ 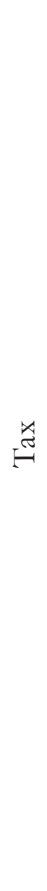 } & $\begin{array}{l}\text { Control rules of foreign } \\
\text { companies }(\text { dummy }=1)\end{array}$ & $\begin{array}{l}\text { Factor } \\
\text { (CFRules) }\end{array}$ & + & $\begin{array}{l}\text { The established rules } \\
\text { should affect the exten- } \\
\text { sion of tax base and } \\
\text { higher CITRs. }\end{array}$ \\
\hline & $\begin{array}{l}\text { Loss of Carry-forward } \\
(\text { dummy }=1)\end{array}$ & $\begin{array}{l}\text { Factor (For- } \\
\text { ward) }\end{array}$ & + & $\begin{array}{l}\text { The unestablished option } \\
\text { of the loss of carry-for- } \\
\text { ward should affect higher } \\
\text { CITRs. }\end{array}$ \\
\hline & $\begin{array}{l}\text { Loss of Carry-back } \\
(\text { dummy }=1)\end{array}$ & Factor (Back) & + & $\begin{array}{l}\text { The unestablished option } \\
\text { of the loss of carry-back } \\
\text { should affect higher } \\
\text { CITRs. }\end{array}$ \\
\hline & $\begin{array}{l}\text { Tax incentives for re- } \\
\text { search and development } \\
(\text { dummy }=1)\end{array}$ & Factor (R\&D) & + & $\begin{array}{l}\text { The unestablished tax in- } \\
\text { centives in the field of sci- } \\
\text { ence and research should } \\
\text { affect higher CITRs. }\end{array}$ \\
\hline & $\begin{array}{l}\text { Transfer pricing rules } \\
(\text { dummy }=1)\end{array}$ & $\begin{array}{l}\text { Factor (Trans- } \\
\text { fer) }\end{array}$ & - & $\begin{array}{l}\text { Established transfer pric- } \\
\text { ing rules should affect the } \\
\text { decline in aggressive tax } \\
\text { planning. }\end{array}$ \\
\hline \multirow{4}{*}{ 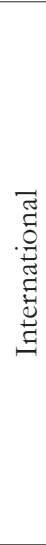 } & $\begin{array}{l}\text { The inflow of foreign } \\
\text { direct investment in rela- } \\
\text { tion to GDP }\end{array}$ & FDI & + & $\begin{array}{l}\text { Growth of foreign direct } \\
\text { investments increases } \\
\text { capital reserves and that } \\
\text { leads to higher CITRs. }\end{array}$ \\
\hline & $\begin{array}{l}\text { Land area above sample } \\
\text { average }(\text { dummy }=1)\end{array}$ & Factor (Big) & + & $\begin{array}{l}\text { A state with the larger } \\
\text { land area has the potential } \\
\text { to reach higher CITRs. }\end{array}$ \\
\hline & Openness $($ dummy $=1)$ & Factor (Inter) & + & $\begin{array}{l}\text { An open state has the } \\
\text { potential to reach higher } \\
\text { CITRs. }\end{array}$ \\
\hline & Globalization index & Global & + & $\begin{array}{l}\text { Better conditions for taxa- } \\
\text { tion lead to higher CITRs. }\end{array}$ \\
\hline \multirow{3}{*}{ 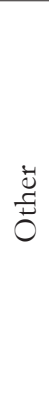 } & $\begin{array}{l}\text { Share of GDP of the state } \\
\text { in relation to total GDP }\end{array}$ & Relative & + & $\begin{array}{l}\text { Size variable of the corpo- } \\
\text { rate sector, growth leads } \\
\text { to a higher CITRs. }\end{array}$ \\
\hline & GDP growth & Growth & + & $\begin{array}{l}\text { A higher GDP growth } \\
\text { leads to higher CITRs. }\end{array}$ \\
\hline & Unemployment rate & Unempl & - & $\begin{array}{l}\text { A higher unemployment } \\
\text { rate leads to a decline in } \\
\text { the corporate sector prof- } \\
\text { itability and lower CITRs. }\end{array}$ \\
\hline
\end{tabular}




\begin{tabular}{|c|c|c|c|c|}
\hline \multirow{2}{*}{ 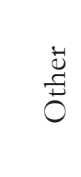 } & Inflation & Infl & + & $\begin{array}{l}\text { A higher inflation rate } \\
\text { leads to higher CITRs. }\end{array}$ \\
\hline & $\begin{array}{l}\text { Natural logarithm GDP } \\
\text { per capita }\end{array}$ & Ln(GDP_PC) & + & $\begin{array}{l}\text { The size of corporate sec- } \\
\text { tor affects CITRs. }\end{array}$ \\
\hline \multicolumn{2}{|c|}{ Time effect } & \multicolumn{3}{|c|}{$\begin{array}{l}\text { CITR may change over the period, which is caused by } \\
\text { the unmeasured facts. }\end{array}$} \\
\hline
\end{tabular}

The subject of the research is the EU-28 in the period 2007-2017. The sample database of the EU-28 member states is derived from Eurostat, OECD, the Tax Attractiveness Index compiled by authors Schanz et al. (2017), globalization index, METR compiled according to the methodology of Devereux and Griffith (1998), published by Bazel, Mintz and Thompson (2018). The explained variables are researched in the $\mathrm{R}$ program environment by using the packages psych, tseries, plm, and aTSA. Prior to modelling, the stacionarity of time series data of explanatory variables based on the KPSS test and on the extended DF test over the period of time 2007-2017 is tested. The analysis is constructed of a combined regression model, a fixed effects model, and a random effects model. The significance of the selected variables entering the models is verified by the KMO criterion. Criteria values below the significance level (0.5) are considered as insufficient and therefore are excluded from the models.

\section{RESULTS AND DISCUSSION}

\subsection{The analysis of STR and METR}

The indicator STR is considered as a determinant of CTRs, which affects the LP decision of mobile capital placement. According to the literature, it provides a space for mutual comparison of the tax burden among states (Spengel et al., 1999).

All EU states implement corporate tax at the central level (Tab. 2). Its level differs from a minimum of $10 \%$ (Bulgaria) over the time period 2007-2017 to 38.7\% (Germany) in 2007, while the long-term highest tax rate is in Malta (35\%) over the time period 2007-2017. The average level of tax rate was $23.1 \%$ (average 2007-2017). A decline in the corporate tax compared to the previous period has been observed in almost all states over the whole period, with the exception of Greece, which increased the rate by $10 \%$ in 2007 and subsequently decreased it by $11 \%$ in 2011 compared to the previous period, Latvia (by 5\% in 2008), Portugal (by 2.5\% in 2010 and 2012) and Slovakia (by $4 \%$ in 2013). Among sates with the lowest tax rates (up to the average of $23.1 \%$ ), almost all new EU member states (with the exception of Estonia and Malta) can be included. The situation has not changed even in 2017. In the context of states' tax competitiveness based on the values of STRs, it can be assumed that the new member states in the field of corporate taxation are more competitive than the old member states. Several states have even announced their expected additional STR reductions, for example the United Kingdom to $17 \%$ in 2020, Luxembourg to $18 \%$. France plans a 5\% reduction by the end of 2019. Member states use other applicable tax rates to influence the behaviour of enterprises and to achieve the economic objectives that were set. An example is the solidarity tax (5\%) applicable in Germany, a reduced tax rate applicable for example in Belgium depending on the turnover (24.25-34.5\% by turnover), 
depending on the type of business, for example in Ireland, Luxembourg or Slovenia. On the contrary, some states add to the tax rate specific types of surcharges, or more precisely licenses (Austria, Slovenia).

The legally determined tax rate does not take into account the construction of the tax base. The evaluation based on the STR only may be inaccurate. An alternative is the METR. Since 2007, a long-term reduction of METR in relation to capital has been observed with the aim to reduce transfers of entrepreneurs' tax preferences between the states. In the EU member states, METR was at a simple average of $15.8 \%$ (average 2007-2017). The rate has varied between the states, ranging from a minimum of $4.2 \%$ (RO) to $34.4 \%$ (in the long term in France) with a maximum of $35.7 \%$ (France). Many larger states, for example France or Germany, dispose of higher METR. Smaller states, such as Denmark, Finland, Ireland, Spain or Sweden, use a lower tax on capital, which significantly influences FDI inflows as a share of GDP. States are increasingly competing with each other to attract new capital flows. Based on the calculations resulting from the comparison of these two indicators, we conclude that the correlation between METR and STR is at the level of $72.6 \%$. STR is not the only source of METR change, for example deduction of costs (Italy), tax exemption from undistributed profits (Estonia), application of accelerated depreciation and other cost reductions (Slovenia) belong there, too. According to Bazel, Minz and Thompson (2018), states that belong to the same regions, or more precisely neighbouring states imitate the tax policies of their neighbours. The EU-28 is characterized by the fact that it consists of former communist states with a very different cultural and historical background. Similar METR levels are observed in the states with innovative systems (e.g. France, Germany, Spain, and the United Kingdom).

Tab. 2 - Descriptive statistics of selected indicators of CITRs. Source: own research

\begin{tabular}{|l|l|l|l|l|l|l|}
\hline \multicolumn{2}{|l|}{ STR (in \%) } & \multicolumn{2}{l}{ METR (in \%) } \\
\hline Cluster & EU-28 & $\begin{array}{l}\text { New Mem- } \\
\text { ber EU-28 }\end{array}$ & $\begin{array}{l}\text { Old } \\
\text { Members } \\
\text { EU-28 }\end{array}$ & EU-28 & $\begin{array}{l}\text { New Mem- } \\
\text { ber EU-28 }\end{array}$ & $\begin{array}{l}\text { Old } \\
\text { Members } \\
\text { EU-28 }\end{array}$ \\
\hline Count & 308 & 143 & 165 & 308 & 143 & 165 \\
\hline Mean & 23.127 & 18.590 & 27.060 & 15.778 & 12.060 & 19.000 \\
\hline St. Dev. & 7.228 & 5.980 & 5.774 & 7.759 & 6.866 & 7.027 \\
\hline Minimum & 10.000 & 10.000 & 12.500 & 4.200 & 4.200 & 6.000 \\
\hline Median & 22.000 & 19.000 & 27.080 & 13.600 & 11.500 & 17.600 \\
\hline Mode & 25.000 & 19.000 & 25.000 & 13.400 & 32.200 & 10.500 \\
\hline Maximum & 38.700 & 35.000 & 38.700 & 35.700 & 32.200 & 35.700 \\
\hline St. Error & 0.412 & 0.500 & 0.449 & 0.442 & 0.574 & 0.547 \\
\hline Kurtosis & -0.823 & 2.150 & 0.753 & 0.001 & 3.227 & -0.228 \\
\hline Skewness & 0.052 & 1.200 & -0.705 & 0.763 & 1.724 & 0.512 \\
\hline Range & 28.700 & 25.000 & 26.200 & 31.500 & 28.000 & 29.700 \\
\hline
\end{tabular}


According to the comparison of the tax rate indicator - STR and MEATR in the EU-28 member states, we assume that despite of effort to harmonize tax systems in the field of corporate taxation, starting with the pursuit of similar (reduced) tax rates up to the harmonization of certain measures (double taxation, transfer pricing, application of withholding tax, restrictions on the payment of dividend tax), tax competition is present among the EU member states. A significant competition is observed separately between the old and the new member states. The original member states are considered to be less competitive. They preferentially criticize tax competition and call for a greater tax harmonization. The new member states are considered to be more competitive.

Based on the comparison of indicators, it is possible to confirm the hypothesis No. 1 that there is a significant tax competition in the field of corporate tax among states of the European Union.

\subsection{Determinants of CITRs in the context of tax competitiveness}

The econometric model of the equation takes into account three sets of explanatory variables in relation to the variable explained, which is CITRs in relation to GDP as an indicator of tax competitiveness in the field of corporate taxation in the EU-28 for the time period 2007-2016 (the reason for shortening the monitored period is data availability). The statistical significance of each model was evaluated on the basis of the R2 determination coefficient and the adjusted $\mathrm{R} 2$ determination coefficient. Considering only statistically significant variables and taking into account the R2 determinant coefficient, models differ from one another. Two models have been compiled (Tab. 3).

In Model A, there were used tax variables in the form of tax rates, namely the statutory tax rate (STR) and the marginal effective tax rate (METR) and their second powers. Subsequently, the foreign direct investment (FDI) variable, the openness factor of the state (Factor(Inter)), and the globalization index (Global). Additionally, other variables affecting the corporate environment in the form of natural logarithm GDP per capita (Ln (GDP_PC)), economic GDP growth (Growth), unemployment (Unempl), and inflation (Infl). In Model A, Hausman's test confirms the suitability of the model selection with the fixed effects for state. According to the KMO criterion, and subsequently on the basis of the p-values of t-statistics, statistically insignificant variables (FDI and METR2, values are shown in the table) were removed.

Given the complexity of tax policy legislation, it is justified to state the difficulty of identifying tax base determinants in order to determine the factors of CITRs. Important categories that affect the tax base have been identified as anti-evasion rules (Factor(Anti)), control rules of foreign companies (Factor(CFRules)), loss of carry-back (Factor(Back)), loss of carry-forward (Factor(Forward)), failure of providing tax incentives for R \& D (Factor(R\&D)), and the existence of transfer pricing rules (Factor(Transfer)). These variables are part of Model B only. This model has highlighted the fact that the statistical significance of STRs decreases with the implementation of other elements modifying the tax base. These variables appeared in the model in the form of dummy variables. Model B has once again proved to be a good choice for a fixed model with effects on the states. According to the KMO criterion, and subsequently on the basis of p-values of t-statistics, statistically insignificant variables (FDI, Factor (CFRules), Factor(R\&D), and METR2, values are shown in the table) were removed. 
Tab. 3 - Key results of the panel regression analysis of CITRs. Source: own research

\begin{tabular}{|c|c|c|}
\hline \multirow[t]{2}{*}{ Independent variables } & \multicolumn{2}{|c|}{$\begin{array}{l}\text { Dependent variable: CITRs in } \\
\text { relation to GDP }\end{array}$} \\
\hline & Model A & Model B \\
\hline STR & $\begin{array}{l}0.21391352 \\
(0.0045447) * *\end{array}$ & $\begin{array}{l}0.17610627 \\
(0.019214) *\end{array}$ \\
\hline $\mathrm{STR}^{2}$ & $\begin{array}{l}-0.32135802 \\
(0.0292061) * \\
\end{array}$ & $\begin{array}{l}-0.25819803 \\
(0.078003)\end{array}$ \\
\hline METR & $\begin{array}{l}0.07840220 \\
(0.0433433) * \\
\end{array}$ & $\begin{array}{l}0.07307598 \\
(0.055853)\end{array}$ \\
\hline METR $^{2}$ & $\begin{array}{l}-0.16712721 \\
(0.1306068) \\
\end{array}$ & $\begin{array}{l}-0.17189680 \\
(0.114532)\end{array}$ \\
\hline Factor(Anti) & - & $\begin{array}{l}0.00647401 \\
(0.034154) *\end{array}$ \\
\hline Factor(CFRules) & - & $\begin{array}{l}0.00245814 \\
(0.147780)\end{array}$ \\
\hline Factor(Forward) & - & $\begin{array}{l}0.00327380 \\
(0.007308) * *\end{array}$ \\
\hline Factor(R\&D) & - & $\begin{array}{l}-0.00047933 \\
(0.682955) \\
\end{array}$ \\
\hline FDI & $\begin{array}{l}0.00040279 \\
(0.6070351) \\
\end{array}$ & $\begin{array}{l}0.00022036 \\
(0.7760231) \\
\end{array}$ \\
\hline Factor(Inter) & \begin{tabular}{|l|}
0.00175683 \\
$(0.0874334)$ \\
\end{tabular} & $\begin{array}{l}0.00168392 \\
(0.097075)\end{array}$ \\
\hline Global & $\begin{array}{l}0.00067542 \\
(0.0519681)\end{array}$ & $\begin{array}{l}0.00077181 \\
(0.030912) *\end{array}$ \\
\hline Growth & $\begin{array}{l}0.01455393 \\
(0.0523331) \\
\end{array}$ & $\begin{array}{l}0.01391806 \\
(0.061799)\end{array}$ \\
\hline Unempl & $\begin{array}{l}-0.08679129 \\
(1.84 \mathrm{e}-10) * * *\end{array}$ & $\begin{array}{l}-0.09270850 \\
(3.255 \mathrm{e}-11) * * *\end{array}$ \\
\hline Infl & $\begin{array}{l}0.02697268 \\
(0.0560818) \\
\end{array}$ & $\begin{array}{l}0.03276983 \\
(0.023826) *\end{array}$ \\
\hline Ln(GDP_PC) & $\begin{array}{l}-0.02340149 \\
(0.0003483) * * * \\
\end{array}$ & $\begin{array}{l}-0.02682288 \\
(7.348 \mathrm{e}-05) * * *\end{array}$ \\
\hline Number of observations & $\begin{array}{l}\mathrm{n}=28, \mathrm{~T}=10 \\
\mathrm{~N}=280\end{array}$ & $\begin{array}{l}\mathrm{n}=28, \mathrm{~T}=10, \\
\mathrm{~N}=280\end{array}$ \\
\hline $\mathrm{p}$-value of F-statistic & $<2.22 \mathrm{e}-16$ & $<2.22 \mathrm{e}-16$ \\
\hline $\mathrm{R}^{2}$ & 0.34012 & 0.37206 \\
\hline Adjusted R² & 0.23923 & 0.26388 \\
\hline
\end{tabular}

Notes: The table shows the values of coefficients for individual models and the p-values of the t-statistics in 
brackets, the significance of the model is indicated at the significance level of 0.001 '***', at the significance level of $0.01^{\text {(**) }}$, at the significance level of $0.05^{\text {'*', }}$, at the significance level of $0.1^{\text {' }}$. .

According to economic theory, both models were based on the underlying assumption of economic theory, supporting the conclusions that CITRs are affected by the level of the STR. For this reason, two variables were included in the tax set, in the form of a STR and its second power STR2. In order to assess the tax competitiveness of states, METR in its basic form and also in the form of second power METR2 are also incorporated in the models. The resulting models consider both explanatory variables to be significant at the chosen significance level. Ceteris paribus, tax rate growth affects CITRs proportionally. The second power of tax rates reaffirms the conclusions that the tax rate itself is not a linearly influencing determinant of CITRs. The evidence regarding the significance of METR2 is weak. The results of decreasing the significance of METR at the chosen level supports the fact that the existence of a regional tax competition is reduced. With a rapid increase of tax rates, the development of CITRs decreases concurrently along with a decrease in the state's competitiveness in corporate taxation. This finding was also supported by the fact that CITRs themselves are also affected by other determinants such as tax rates. From the perspective of binary variables affecting the development of CITRs, it is reasonable to mention the implemented anti-evasion rules Factor(Anti) and the loss of carry-forward Factor(Forward) options. Legislative rules are often considered to be significant tax incentives, especially for small enterprises and start-ups, which implies the justification of their introduction and perception within tax competitiveness.

Based on determinants reflecting the corporate sector in state, the size of the corporate sector was observed, monitored by the secondary data of GDP growth and natural logarithm GDP per capita and GDP growth rate. These variables have confirmed that GDP growth, which is an indicator of the growing corporate sector as well as economic growth in the state, also leads to a growth of CITRs. Their growth in the corporate sector is linked to the increasing competitiveness of enterprises and the improvement of business conditions in the state.

Among the international factors influencing corporate taxation and its competitiveness, the inflow of foreign direct investment FDI was part of the analysis. Based on the economic literature, FDI growth in the state increases CITRs as part of the EU-28 assessment as a whole. However, this determinant did not appear in the analyses performed. The reason may be the justification of states and dividing these into a block of old and new member states. It is the old member states that dispose of higher dependency on FDI inflow to the state compared to the new member states, where this determinant does not often appear at the chosen level of significance. This result may also express the economic integration of FDI, which is falling in competition in the integrated field, while the competition between blocks is unclear. From other international factors, the openness of the country Factor (Inter) along with globalization observed by the globalization index, were considered as statistically significant variables. The determination that a state is considered to be open compare to the other states appearing in the model has a positive effect on the increase of CITRs in relation to GDP.

The effect of a higher level of inflation and lower level of unemployment affects the growth of CITRs. The level of inflation and its positive impact on the development of the explained variable is part of several studies. Barro and Furman (2018) define inflation as a determinant of 
CITRs and their conclusions support the expected assumptions of relations, as a higher level of GDP leads to a wider output, thereby the growth of inflation affects productivity growth, which consequently positively affects the corporate sector, its competitiveness, and CITRs. The effect of unemployment is linked to the productivity of the corporate sector (Clausing, 2007; Kawano \& Slemrod, 2016).

According to empirical research, the determinants of corporate taxation competitiveness include tax determinants that dispose of a direct link to the corporate tax structure itself (tax rates), determinants affecting the corporate sector (GDP growth, natural logarithm GDP per capita), international factors affecting the corporate sector (openness and globalization), cyclical determinants (inflation and unemployment) and specific determinants reflecting the tax base and the corporate environment in the state (anti-evasion rules and loss of carry-forward options in particular). International interactions affect a significant relation by the tax competitiveness of a state in the form of a change in CITRs. In this part of the analysis, the FDI factor did not show to be as significant at the chosen level of significance. As it is possible to compare CITRs in relation to GDP or to total tax revenues, this implied trend could be the result of reasons other than the tax systems themselves.

The selected variables in the models are statistically significant determinants that can affect the level of CITRs and therefore the state's competitiveness in the corporate taxation field. Based on the stated findings, the assumptions of hypothesis No. 2 can be considered verified at the chosen level of significance.

Individual tax systems in the EU do not exist in isolation, but compete with each other. Both the EU and OECD states have shown continual declines of rates from an average of $50 \%$ in the year 1985 to rates between 30-35\% in the year 1995. Some studies show (in: Patterson \& Serrano, 1998) that tax competition effectively limits the trend of tax increases in the states with a relatively high tax rate, and has encouraged the convergence of the EU member states within the tax field. Presently, in the EU rates are around the level of $23 \%$ and continue to decline. Tanzi (1996) states that the choice of low corporate taxation leads to a low overall public spending. For example, low corporate income tax rates of LP can be attractive for new investments, but other factors such as landscape infrastructure also interfere with the attractiveness of the corporate environment.

\section{CONCLUSION}

It is necessary to point out the fact that states attempt to preserve their tax sovereignty, thereby use opportunities for tax competitiveness growth, in particular through decreasing tax rates to increase competitiveness. When enterprises are deciding about the place of their mobile bases, the amount of taxable income in the state and consequently the amount of CITRs are also affected. These factors are determined in the context of tax competition as well as by international factors affecting the corporate sector, cyclical determinants, and specific determinants that reflect the tax base and the corporate environment in the state. Taking into account the conclusions of the analyses carried out as well as the conclusions of the analyses from previous empirical literature, tax competition in the EU remains ever present among the member states, and the analysis provides no convictive empirical evidence about the state of LP income tax harmonization. 


\section{Acknowledgement}

This research was supported by the VEGA project No. 1/0430/19 Investment decision-making of investors in the context of effective corporate taxation.

References

\section{References}

1. Auerbach, A. J. (2006). Why Have Corporate Tax Revenues Declined? Another Look. (Working paper No. 12463). Cambridge: National Bureau of Economic Research.

2. Baltagi, B. H., Egger P., \& Pfaffermayr, M. (2007). Estimating Models of Complex FDI: Are There Third-Country Effects? Journal of Econometrics, 140(1), 260-281.

3. Barro, R. \& Furman, J. (2018). The macroeconomic effects of the 2017 tax reform. In The Brookings Papers on Economic Activity (Spring). Available at: https://www.brookings.edu/bpeaarticles/macroeconomic-effects-of-the-2017-tax-reform/

4. Bazel, P., Mintz, J. \& Thompson, A. (2018). Tax Competitiveness Report: The Calm Before the Storm. In The School of Public Policy Publications: SPP Research Paper (11:7). Available at: https://www.policyschool.ca/wp-content/uploads/2018/02/2017-TaxCompetitiveness-Bazel-Mintz-Thompson-final.pdf

5. Bénassy-Quéré, A., Fontagné, L., \& Lahrèche-Révil, A. (2000). Foreign Direct Investment and the Prospects for Tax Co-Ordination in Europe. (Working paper No. 2000/06). Paris: Centre d'Études Prospectives et d'Informations Internationales.

6. Brill, A. \& Hassett, K. (2007). Revenues-Maximizing Corporate Income Taxes: The Laffer Curve in OECD Countries. (Working paper No. 137). Washington, D.C.: American Enterprise Institute for Public Policy Research.

7. Chirculescu, M. F. (2018). Advantages and Disadvantages of Tax Competition in the European Union. Economy Series, 1, 186-192.

8. Clausing, K. (2007). Corporate tax revenues in OECD countries. International Tax and Public Finance, 14 (1), 115-133. https://doi.org/10.1007/s10797-006-7983-2.

9. Congressional Budget Office's (CBO). (2017). International Comparisons of Corporate Income Tax Rates. Available at: https://www.cbo.gov/system/files/115th-congress-20172018/reports/52419-internationaltaxratecomp.pdf

10. Davies, R. \& Voget, J. (2008). Tax competition in an expanding European Union. (Working paper No. 08/30). Oxford: Centre for Business Taxation.

11. Devereux, M. P. \& Freeman, H. (1995). The impact of tax on foreign direct investment: empirical evidence and the implications for tax integration schemes. International Tax and Public Finance, 1995 (2), 85-106.

12. Devereux, M. P. \& Griffith, R. (1998). Taxes and local production: evidence from a panel of US multinationals. Journal of Public Economics, 68 (1), 335-367.

13. Devereux, M. P., Lockwood, B. \& Redoano, M. (2008). Do Countries Compete over Corporate Tax Rates? Journal of Public Economics, 92 (5/6), 1210-1235. https://doi. org/10.1016/j.jpubeco.2007.09.005

14. Edward, C. \& Rugy, V. (2002). International Tax Competition, Economic Freedom of the 
World, Policy Analysis. (Annual Report No. 431). Washington, D.C.: Cato Institute.

15. European Commission (EC) (2018). Taxation Trends in European Union - Data for the EU Member States, Iceland and Norway. Bietlot: European Union.

16. Griffith, R. \& Klemm, A. (2004). What has been the Tax Competition Experience of the Latest 20 Years? (Working papers W04/05). London: Institute for Fiscal Studies.

17. Gropp, R., \& Kostial, K. (2000). The Disappearing Tax Base: Is Foreign Direct Investment Eroding Corporate Income Taxes? (Working paper No. 31). Frankfurt am Main: European Central Bank.

18. Kalaš, B., Mirović, V. \& Pjanić, M. (2017). Economic and Tax Competitiveness in Selected South East European Countries. Economic Analysis, 50 (3/4), 55-65.

19. Kawano, L. \& Slemrod, J. B. (2012). The effect of tax rates and tax bases on corporate tax revenues: estimates with new measures of the corporate tax base. (Working paper No. 12/19). Oxford: Oxford University Centre for Business Taxation.

20. Kawano, L. \& Slemrod, J. B. (2016). How do corporate tax bases change when corporate tax rates change? With implications for the tax rate elasticity of corporate tax revenues. International Tax and Public Finance, 23 (1), 401-433. https://doi.org.10.1007/s10797-015-9375y

21. Keen, M. (2017). Tax competition. In S. N. Durlauf, \& L. E. Blume (Eds.), The New Palgrave Dictionary of Economics (6516-6523). London: Palgrave Macmillian. https://doi. org/10.1007/978-1-349-58802-2

22. Matthews, S. (2011). What is a Competitive Tax System? (Working papers No.2). Paris: OECD Publishing. https://doi.org/10.1787/22235558

23. Mintz, J. \& Weichenrieder, A. (2010). The Indirect Side of Direct Investment. Cambridge: MIT Press.

24. Mitchell, D. J. (2004). The Economics of Tax Competition: Harmonization vs. Liberalization. (Briefing Paper). London: Adam Smith Institute. Retrieved from https://static1. squarespace.com/static/56eddde762cd9413e151ac92/t/5ae9ba8970a6ad102dc12433/152526 7090079/tax-competition.pdf

25. Motta, M. \& Norman, G. (1996). Does Economic Integration Cause Foreign Direct Investment? International Economic Review, 37 (4), 757-783.

26. OECD. (2011). OECD 50th Anniversary Challenges In Designing Competitive Tax Systems. Tax Reform Trends in OECD Countries. Retrieved from https://www.oecd. org/ctp/48193734.pdf

27. OECD. (2014). The Distributional Effects of Consumption Taxes in OECD Countries. (OECD Tax Policy Studies No. 22). Paris: OECD Publishing. https://doi.org/10.1787/9789 264224520-en.

28. Overesch, M. \& Rincke, J. (2011). What Drives Corporate Tax Rates Down? A

Reassessment of Globalization, Tax Competition, and Dynamic Adjustment to Shocks. Scandinavian Journal of Economics, 113 (3), 579-602. https://doi.org/10.1111/j.14679442.2011.01650.x 
29. Patterson, B. \& Serrano, A. M. (1998). Tax competition in the European Union. (Working paper No. PE 167.812). Luxembourg: European Parliament.

30. Remeur, C. (2015). Tax policy in the EU: Issues and Challenges. Luxembourg: European Parliament. https://doi.org/10.2861/249007

31. Schanz, D., Keller, S., Dinkel, A., Fritz, J. \& Grosselfinger, Ch. (2017). The Tax Attractiveness Index: Methodology. Munich: LMU Munich.

32. Schön, W. (2003). Tax Competition in Europe - General Report. Amsterdam: IBFD.

33. Široký, J., Stř́llková, R. \& Krajňák, M. (2016). Trend, development, role and importance of corporate taxes in the EU. Brno: Akademické nakladatelství CERM.

34. Slemrod, J. (1990). The Impact of the Tax Reform Act of 1986 on Foreign Direct Investment to and from the United States. In J. Slemrod (Ed.), Do Taxes Matter? The Impact of the Tax Reform Act of 1986. Cambridge: MIT Press.

35. Spengel, Ch., Caron\&Stevens \& Baker\&McKenzie. (1999). Survey of the Effective Tax Burden in the European Union - Impact on Domestic and Cross-Border Financing, Investment and Location Decisions. Amsterdam: Report commissioned by the Ministry of Finance in the Netherlands.

36. Stiglitz, J. E. \& Rosengard, J. K. (2015). Economic of the Public Sector. London: W.W. Norton \& Company.

37. Stolojan, T. \& Tatarcan R. (2002). Integrarea şi politica fiscală europeană. Braşov: Infomarket.

38. Streif, F. (2015). Tax Competition in Europe - Europe in Competition with Other World Regions?. (Discussion paper No. 15/082). Manheim: Centre for European Economic Research (ZEW). Available at: http://ftp.zew.de/pub/zew-docs/dp/dp15082.pdf

39. Tanzi, V. (1996). Globalization, Tax Competition and the Future of Tax Systems. (Working paper No. 96/141). Washington, D.C.: International Monetary Fund Working Paper.

40. Winner, H. (2005). Has Tax Competition Emerged in OECD Countries? Evidence from Panel Data. International Tax and Public Finance, 12 (5), 667-687.

\section{Contact information}

doc. Ing. Anna Banociova, PhD.

Technical University of Košice

Faculty of Economics, Department of Finance

Nèmcovej 32, 04001 Košice

Slovak Republic

E-mail:anna.banociova@tuke.sk

Ing. Slavomira Tablova, PhD.

Technical University of Košice

Faculty of Economics, Department of Finance

Nèmcovej 32, 04001 Košice

Slovak Republic

E-mail: slavomira.tablova@tuke.sk

ORCID: 0000-0002-7802-7102 